\title{
Spectrophotometric Determination of Mesalazine by Diazotisation- Coupling Method with Resorcinol
}

\author{
Rawa A. Zakaria \\ Department of Chemistry \\ College of Education \\ Mosul University
}

(Received 23/ 9/ 2008 ; Accepted 26/1/2009)

\begin{abstract}
A simple spectrophotoemtric method for the determination of mesalazine [5aminosalicylic acid; (5-ASA)] in aqueous solution is achieved. The method is based on the reaction of mesalazine, with excess nitrite, in an acidic medium, to produce the corresponding diazonium salt. After the removal of residual nitrite with sulphamic acid, the diazonium salt is coupled with resorcinol reagent in basic medium to produce, an intense orange coloured water-soluble and stable azo-dye which exhibits maximum absorption at $471 \mathrm{~nm}$. Beer's law is obeyed in the concentration range of $10-300 \mu \mathrm{g}$ of mesalazine in a final volume of $25 \mathrm{ml}$ i.e., 0.4-12 ppm with a molar absorptivity of $2.9480 \times 10^{4} 1 . \mathrm{mol}^{-1} . \mathrm{cm}^{-1}$ and Sandell sensitivity index of $0.0051 \mu \mathrm{g} . \mathrm{cm}^{-2}$, a relative error of -0.96 to $-0.23 \%$ and relative standard deviation of \pm 1.05 to $\pm 0.37 \%$ depending on the concentration level. The proposed method has been applied successfully to determine mesalazine in pharmaceutical preparation (capsules).

\section{القير الملي لاميزالازن بلستخدلمطرقة الأزوتة ولافترلنمع الربسورسينظل}

\section{الملغص}

يتضمن البحث طريقةطفية بسيطة لقدير الميزالازين [ 5 -أمينو حلمض المللسيك، (5-ASA) في الوبط المائي بطريقة الأزوتة والاقتران. تعتمد الطريقة على مفاعلة الميزالازين مع زيقة زياة من النتريت

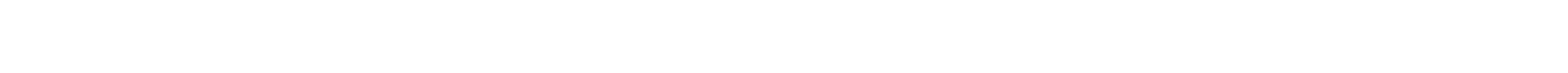

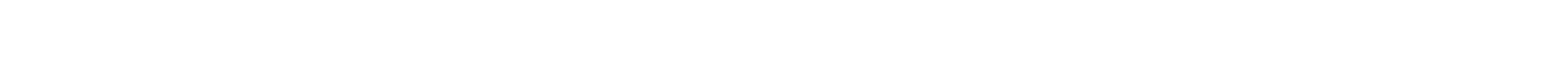

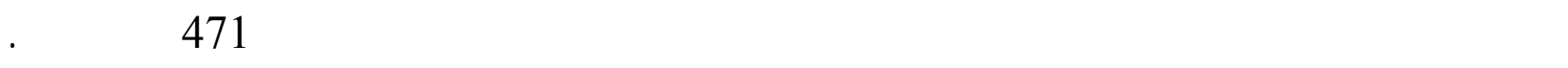

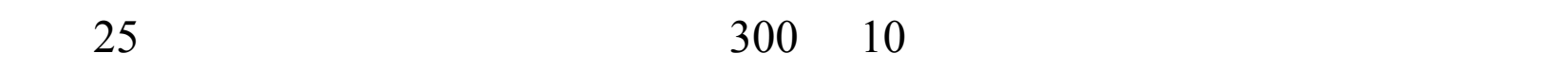

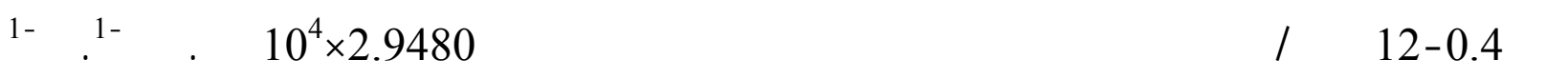

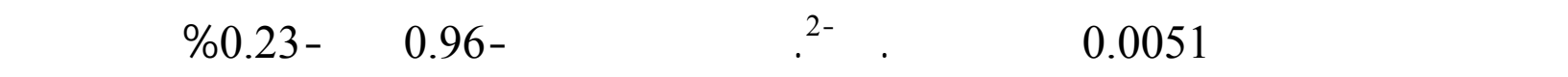




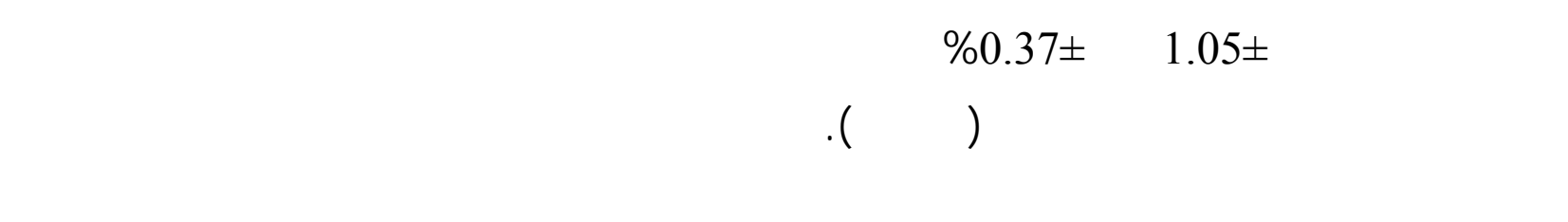

INTRODUCTION

Mesalazine [5-Amino salicylic acid; (5-ASA)] is an agent widely used in the treatment of inflammatory bowel disease (IBDs), is metabolized in organism to the principal biotransformation product, $\mathrm{N}$-acetyl-5-ASA, is a polar compound and besides it exhibits amphoteric properties (Liu et al., 1995 and Nobilis et al., 2006).

Different methods have been reported for the determination mesalazine including: liquid chromatographic technique which was used to determine 5-ASA and its metabolite $\mathrm{N}$-acetyl-5-aminosalicylic acid in plasma and urine by using a spectrofluoimetric detector, excitation at $311 \mathrm{~nm}$. The lower limit of detection was $20 \mathrm{ng} / \mathrm{ml}$ and a relative standard deviation was below 6.7\% (Bystrowska et al., 2000).

High performance liquid chromatography (HPLC) method was employed to measure 5-ASA and its metabolities in blood plasma. Chromatographic analysis were performed on a $250-4 \mathrm{~mm}$ column with UV photodiode-array and fluorescence detectors (Nobilis et al., 2006).

A micellar electrokinetic chromatographic (MEKC) has been used for the estimation of mesalazine and its major impurities, the method used capillary chromatography column select fused-silica with a buffer solution ( $\mathrm{pH} \mathrm{10.20),} \mathrm{methanol,}$ sodium dodecyl sulfate (SDS), tetrabutylammonium bromide (TBAB) as a mobile phase. (Gotti et al., 2001).

Mesalazine was determined by three different methods: the first method (HPLC) was carried out with a $\mathrm{C}_{18}$ column and a mobile phase was constituted of $30 \mathrm{mmol} / \mathrm{l}$ monobasic phosphate buffer ( $\mathrm{pH} 7.0)$ and methanol (70:30; v/v), with $25 \%$ tetrabutylammonium hydrogen sulphate used ultraviolet detection at $254 \mathrm{~nm}$, the second method used 1,1-diphenyl-2-picrylhydrazyl radicals (DPPH) at 517nm and using $100 \mathrm{mmol} / 1$ acetate buffer, $\mathrm{pH} 5.5$, ethanol and $250 \mu \mathrm{mol} / 1$ ethanolic solution of DPPH and the third method nitrosation was accomplished using a platinum electrode and standard $0.1 \mathrm{~mol} / 1$ sodium nitrite as titrant solution, the experimental recoveries were between 72.5 and $99.9 \%$. All proposed methods can be used for the reliable quantitation of 5-ASA in pharmaceutical dosage forms (Rafael et al., 2007).

A differential pulse voltametry method was employed to determine 5-ASA in tablet using a glassy carbon electrode in Britton-Robinson buffer ( $\mathrm{pH} 1.81$ ), the peak current gave a linear relationship in the concentration range $1 \times 10^{-4}$ and $2 \times 10^{-6}$ molarity, the recovery was $101.23 \%$ with a relative standard deviation of $1.35 \%$ (Nigovic and Imunic, 2003).

A spectrophotometric method for the determination of microgram amounts $(0.16-$ $8 \mu \mathrm{g} / \mathrm{ml}$ ) of mesalazine based on the oxidative coupling with 2,6-xylenol in the presence of sodium metaperiodate in alkaline medium to form a blue indophenol dye which has maximum absorption at $610 \mathrm{~nm}$ with a molar absorptivity is $133161 . \mathrm{mol}^{-1} . \mathrm{cm}^{-1}$ (AlFakhry, 2006).

Another spectrophotometric method was applied for the determination of phenols based on a multicommuted flow system. It was based on oxidative coupling of phenolic 
compounds with 4-amino-antipyrine in alkaline medium containing potassium hexacyanan ferrate (III). The detection limit was $1 \mu \mathrm{g} / 1$ phenol. (Lupetti et al., 2004).

A colouremetric method has been developed for the determination of 5-ASA in urine and feces using Bratton-Marshall reaction to form a violet product with absorption at $560 \mathrm{~nm}$. Beer's law was obeyed in the concentration range $0-70 \mu \mathrm{g} / \mathrm{ml}$ (Pieniaszek and Bates, 1975).

Also, mesalazine has been determined by galvanostatic coulometric method in pharmaceutical preparations using reactions of electrogenerated bromide and chlorine with mesalazine. The end-point of coulometric titration was determined aperometrically with two polarized platinum electrodes. Procedures for the galvanostatic coulometric determination of 2.4 to $19.2 \mu \mathrm{g} / \mathrm{ml}$ with relative standard deviation varied from 1 to $5 \%$ (Abdullin et al., 2002).

The objective of the investigation reported in this paper is to introduce spectrophotometric method for the determination of 5-ASA. Based on the diazotization of 5-ASA and coupling with resorcinol reagent and applying the method to the determination of 5-ASA in pharmaceutical preparation (capsules).

\section{EXPERIMENTAL}

Spectral absorbance measurements are carried out on double beam spectrophotometric Shimadzu (UV-160A) and UV-visible spectrophoto-meter CECILCE 1021 digital single beam using $1 \mathrm{~cm}$ silica cells.

\section{Reagents}

All chemicals used are of the highest purity available.

Working mesalazine (5-ASA) solution, $50 \mu \mathrm{g} / \mathrm{ml}$. A $0.01 \mathrm{~g}$ of mesalazine supplied by (Fluka) is dissolved in $10 \mathrm{ml}$ distilled water, and the volume is completed to $200 \mathrm{ml}$ in a volumetric flask.

Hydrochloric acid solution, 1N. This solution is prepared by diluting $8.5 \mathrm{ml}$ of the concentrated acid to $100 \mathrm{ml}$ with distilled water.

Sodium nitrite solution, $\mathbf{1 \%}$. This solution is prepared by dissolving $1 \mathrm{~g}$ of sodium nitrite in $100 \mathrm{ml}$ distilled water in a volumetric flask.

Sulphamic acid solution, 3\%. A $3 \mathrm{~g}$ of sulphamic acid is dissolved in $100 \mathrm{ml}$ distilled water.

Resorcinol solution, $\mathbf{0 . 1 \%}$. This solution is prepared by dissolving $0.1 \mathrm{~g}$ of resorcinol in distilled water in a $100 \mathrm{ml}$ volumetric flask.

Sodium hydroxide solution, $1 \mathbf{N}$. This solution is prepared by appropriate dilution of the concentrated (Fluka) solution with distilled water and then transferred to a plastic bottle.

Mesacol capsules solution 50 $\mathrm{\mu g} / \mathrm{ml}$. Weight and mix the contents of ten capsules (each one contains $400 \mathrm{mg}$ mesalazine), an accurately weighed amount of powder $(0.0111 \mathrm{~g})$ 
equivalent to $0.01 \mathrm{~g}$ mesalazine is dissolved in $10 \mathrm{ml}$ of absolute ethanol and $30 \mathrm{ml}$ distilled water, after filtration of the solution, the volume is completed to $200 \mathrm{ml}$ of distilled water in a volumetric flask to prepare a solution of $50 \mathrm{ppm}$ mesalazine.

\section{Recommended Procedure and Calibration Graph}

To a series of $25 \mathrm{ml}$ volumetric flasks aliquots covering the range of $10-400 \mu \mathrm{g}$ (0.4-16 ppm) of mesalazine are transferred, $0.5 \mathrm{ml}$ of $1 \mathrm{~N} \mathrm{HCl}$ is then added and the mixtures are shaken. Then $0.5 \mathrm{ml}$ of $1 \%$ sodium nitrite solution is added and the mixtures are allowed to stand for 3 minutes.

Then $0.3 \mathrm{ml}$ of $3 \%$ sulphamic acid solution is added and the mixtures are after that $1.5 \mathrm{ml}$ of sodium hydroxide solution $(1 \mathrm{~N})$ is added, then the volumes are completed to the mark with distilled water. After 10 minutes the absorbance are read at $471 \mathrm{~nm}$ against blank solution, using $1 \mathrm{~cm}$ matched cells. (Fig. 1) shows the calibration curve which indicates that Beer's law is obeyed over the concentration range $10-300 \mu \mathrm{g} / 25 \mathrm{ml}$ final volume, i.e., $0.4-12 \mathrm{ppm}$ and concentration above $300 \mu \mathrm{g} / 25 \mathrm{ml}$ gives negative deviation. The molar absorptivity is $2.9480 \times 10^{4} 1 . \mathrm{mol}^{-1} . \mathrm{cm}^{-1}$.

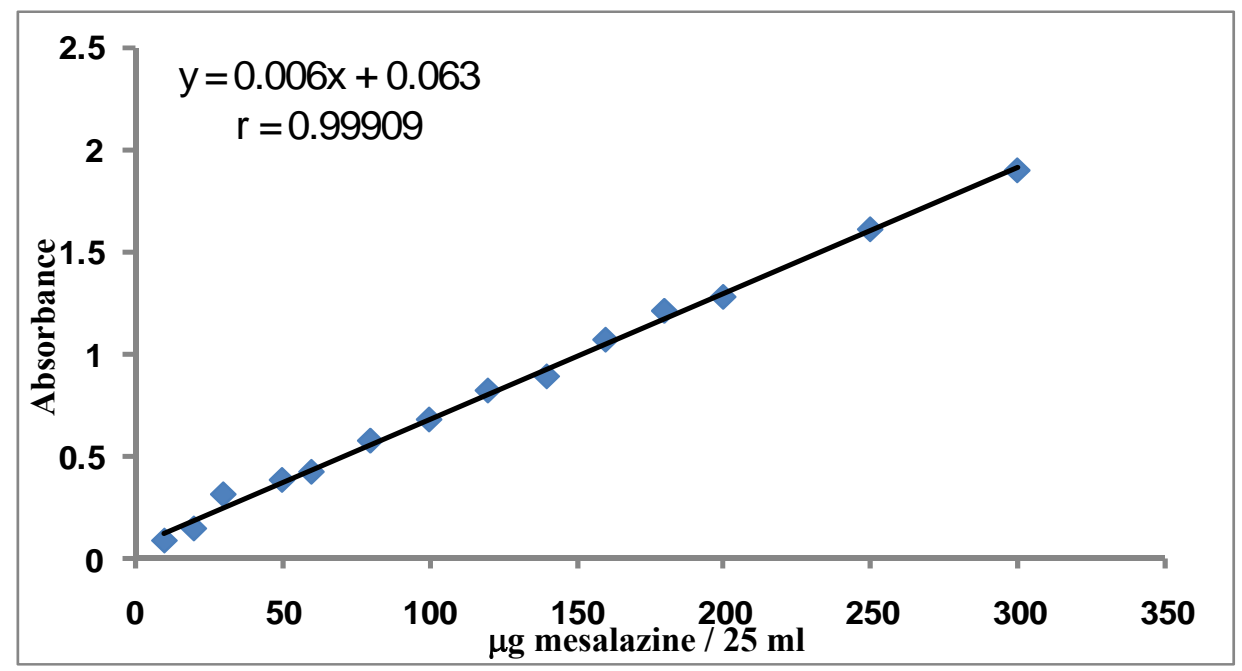

Fig.1: Calibration graph for mesalazine determination using resorcinol as coupling reagent

\section{RESULTS AND DISCUSSION}

For the subsequent experiments, $50 \mu \mathrm{g}$ of mesalazine is taken in $25 \mathrm{ml}$ final volumes and absorbance measurements are performed at $471 \mathrm{~nm}$.

\section{Principle of the method}

Mesalazine is reacted with excess nitrite in acidic medium to form the corresponding diazonium salt:

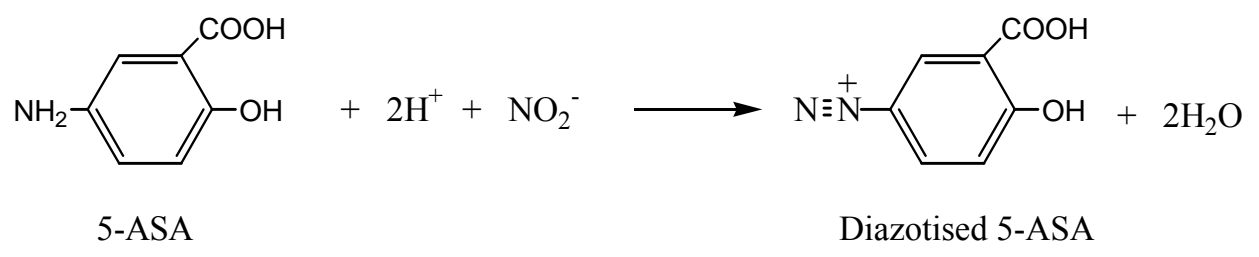


The residual nitrite (as nitrite acid) which was undesirable due to its side reaction, such as, nitrosation of coupling agent (Bladyga et al., 1999). Therefore, it should be removed by sulphamic acid which reacts more fast than urea:

$$
\mathrm{HNO}_{2}+\mathrm{H}_{2} \mathrm{~N}-\mathrm{SO}_{3} \mathrm{H} \longrightarrow \mathrm{N}_{2} \uparrow+\mathrm{H}_{2} \mathrm{O}+\mathrm{H}_{2} \mathrm{SO}_{4}
$$

The colored solution formed by coupling diazotized 5-ASA with resorcinol in alkaline medium.

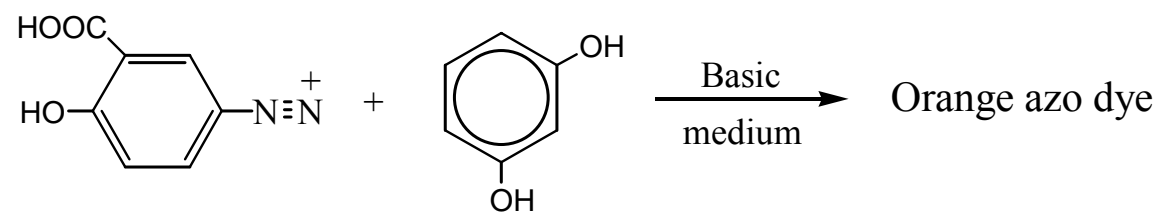

\section{Study of the Optimum Reaction Conditions}

The various parameters effecting and related the colour intensity of the dye have been studied and optimum conditions are selected.

\section{Effect of acids on the diazotization}

The effect of the amount of different acid (weak and strong) for the diazotization of 5-ASA, have been investigated. The results are indicated that $0.5 \mathrm{ml}$ of $1 \mathrm{~N} \mathrm{HCl}$ produces the highest intensity for the dye, so it has been selected in the subsequent experiments(Table 1).

Table 1: Effect of acid on absorbance

\begin{tabular}{|c|c|c|c|c|c|c|}
\hline \multirow{2}{*}{$\begin{array}{c}\text { solution } \\
\text { 1N acid used }\end{array}$} & \multicolumn{6}{|c|}{ Absorbance(A)/ml of acid used } \\
\cline { 2 - 7 } & $\mathbf{0}$ & $\mathbf{0 . 2}$ & $\mathbf{0 . 5}$ & $\mathbf{0 . 7}$ & $\mathbf{1}$ & $\mathbf{1 . 5}$ \\
\cline { 2 - 7 } & 0.305 & 0.324 & 0.350 & 0.344 & 0.300 & 0.309 \\
\hline $\mathrm{HCl}$ & 0.309 & 0.317 & 0.343 & 0.337 & 0.297 & 0.243 \\
\hline $\mathrm{HNO}_{3}$ & 0.319 & 0.315 & 0.322 & 0.319 & 0.262 & 0.219 \\
\hline $\mathrm{H}_{2} \mathrm{SO}_{4}$ & 0.314 & 0.298 & 0.317 & 0.295 & 0.224 & 0.132 \\
\hline $\mathrm{CH}_{3} \mathrm{COOH}$ & & & & & & $\mathbf{A}$ \\
\hline
\end{tabular}

\section{Effect of nitrite amount and time}

The color is reached maximum intensity when using $0.5 \mathrm{ml}$ of $1 \%(\mathrm{w} / \mathrm{v})$ sodium nitrite solution with 3 minutes reaction time, it seems that diazotization of 5-ASA is fast 
Table 2: The effect of sodium nitrite amount and time on absorbance

\begin{tabular}{|c|c|c|c|c|c|c|}
\hline \multirow{2}{*}{$\begin{array}{c}\text { ml of 1\% (w/v) } \\
\text { NaNO }_{2} \text { solution }\end{array}$} & \multicolumn{7}{|c|}{ Absorbance/minute standing time } \\
\cline { 2 - 7 } & $\mathbf{0}$ & $\mathbf{1}$ & $\mathbf{2}$ & $\mathbf{3}$ & $\mathbf{4}$ & $\mathbf{5}$ \\
\hline 0.1 & 0.303 & 0.357 & 0.372 & 0.380 & 0.374 & 0370 \\
\hline 0.2 & 0.300 & 0.335 & 0.340 & 0.372 & 0.367 & 0.362 \\
\hline 0.3 & 0.290 & 0.345 & 0.372 & 0.376 & 0.370 & 0.368 \\
\hline 0.5 & 0.331 & 0.360 & 0.376 & 0.386 & 0.382 & 0.360 \\
\hline 0.7 & 0.211 & 0.287 & 0.243 & 0.238 & 0.233 & 0.221 \\
\hline
\end{tabular}

\section{Effect of sulphamic acid amount and time}

The presence of unreacted nitrite is undesirable in diazotization reaction. Therefore, it should be removed by sulphamic acid which fastly reacts with nitrite. The results indicated that $0.3 \mathrm{ml}$ of $3 \%$ sulphamic acid solution with 3 minutes standing time are considered to be the most suitable(Table 3 ), and therefore are selected subsequently.

Table 3: The effect of sulphamic acid amount and time on absorbance

\begin{tabular}{|c|c|c|c|c|c|c|c|}
\hline \multicolumn{2}{|c|}{$\begin{array}{c}\text { ml of } \\
\text { sulphamic }\end{array}$} & \multicolumn{6}{|c|}{ Absorbance/minute standing time } \\
\cline { 2 - 8 } & $\mathbf{0}$ & $\mathbf{1}$ & $\mathbf{2}$ & $\mathbf{3}$ & $\mathbf{4}$ & $\mathbf{5}$ \\
\hline \multirow{2}{*}{0} & $\mathrm{~S}$ & 0.030 & 0.036 & 0.133 & 0.162 & 0.183 & 0.212 \\
& $\mathrm{~B}$ & 0.114 & 0.152 & 0.157 & 0.158 & 0.154 & 0.142 \\
\hline \multirow{2}{*}{0.1} & $\mathrm{~S}$ & 0.072 & 0.090 & 0.341 & 0.335 & 0.301 & 0.343 \\
& $\mathrm{~B}$ & 0.116 & 0.180 & 0.163 & 0.183 & 0.169 & 0.155 \\
\hline \multirow{2}{*}{0.2} & $\mathrm{~S}$ & 0.120 & 0.293 & 0.346 & 0.367 & 0.382 & 0.361 \\
& B & 0.165 & 0.149 & 0.158 & 0.165 & 0.160 & 0.143 \\
\hline \multirow{2}{*}{0.3} & $\mathrm{~S}$ & 0.336 & 0.325 & 0.358 & 0.387 & 0.370 & 0.360 \\
& B & 0.076 & 0.067 & 0.063 & 0.060 & 0.057 & 0.045 \\
\hline \multirow{2}{*}{0.5} & S & 0.389 & 0.346 & 0.337 & 0.376 & 0.375 & 0.320 \\
& B & 0.077 & 0.075 & 0.021 & 0.030 & 0.018 & 0.083 \\
\hline \multirow{2}{*}{0.7} & S & 0.360 & 0.297 & 0.319 & 0.343 & 0.368 & 0.318 \\
& B & 0.084 & 0.026 & 0.017 & 0.044 & 0.018 & 0.016 \\
\hline
\end{tabular}




\section{Effect of resorcinol amount}

The effect of resorcinol amount on the color intensity of the dye has been studied. From the results, it can be observed that $4 \mathrm{ml}$ of $0.1 \%$ resorcinol is the more suitable amount which gives the highest value of absorbance for the azo-dye formed and the highest value of correlation coefficient (Table 4).

Table 4: The effect of resorcinol amount

\begin{tabular}{|c|c|c|c|c|c|c|c|}
\hline \multirow{2}{*}{$\begin{array}{c}\text { ml of resorcinol } \\
\mathbf{( 0 . 1 \% )}\end{array}$} & $\mathbf{2 0}$ & $\mathbf{5 0}$ & $\mathbf{7 0}$ & $\mathbf{1 0 0}$ & $\mathbf{1 5 0}$ & $\mathbf{2 0 0}$ & $\mathbf{r}$ \\
\cline { 2 - 8 } & & & & & & & \\
\hline $\mathbf{1}$ & 0.142 & 0.382 & 0.397 & 0.528 & 0.804 & 1.098 & 0.993326 \\
\hline $\mathbf{2}$ & 0.153 & 0.375 & 0.395 & 0.577 & 0.869 & 0.166 & 0.996388 \\
\hline $\mathbf{3}$ & 0.165 & 0.380 & 0.409 & 0.604 & 0.884 & 0.1204 & 0.99692 \\
\hline $\mathbf{4}$ & 0.179 & 0.385 & 0.436 & 0.674 & 0.914 & 0.1216 & 0.998218 \\
\hline $\mathbf{5}$ & 0.122 & 0.308 & 0.413 & 0.545 & 0.900 & 0.104 & 0.997061 \\
\hline
\end{tabular}

\section{Effect of time on color development}

The effect of time on the development and stability period of the coloured dye is investigated under the optimum conditions described above for 5-ASA. From the experimental data, it has been noticed that the azo-dye reached maximum absorbance after 10 minutes and remains stable at least for another 50 minutes when the concentrations of 5-ASA was $\leq 50 \mu \mathrm{g} / 25 \mathrm{ml}$. But it was stable for only 30 minutes when the concentration of 5-ASA was $\geq 100 \mu \mathrm{g} / 25 \mathrm{ml}$. However, several measurements can be performed in both cases (Table 5).

Table 5: The effect of time on absorbance

\begin{tabular}{|c|c|c|c|c|c|c|c|c|}
\hline \multirow{2}{*}{$\begin{array}{c}\boldsymbol{\mu g} \text { of 5-ASA/25 } \\
\text { ml }\end{array}$} & \multicolumn{7}{|c|}{ Absorbance / minute standing time } \\
\cline { 2 - 9 } & $\mathbf{0}$ & $\mathbf{5}$ & $\mathbf{1 0}$ & $\mathbf{2 0}$ & $\mathbf{3 0}$ & $\mathbf{4 0}$ & $\mathbf{5 0}$ & $\mathbf{6 0}$ \\
\hline 20 & 0.136 & 0.140 & 0.144 & 0.145 & 0.145 & 0.146 & 0.146 & 0.145 \\
\hline 50 & 0.379 & 0.382 & 0.385 & 0.385 & 0.384 & 0.383 & 0.383 & 0.380 \\
\hline 100 & 0.665 & 0.673 & 0.677 & 0.676 & 0.645 & 0.636 & 0.625 & 0.618 \\
\hline
\end{tabular}




\section{Effect of surfactant}

The results indicated that addition of different types with different amounts of surfactants give no useful effect. Therefore, it has been recommended to eliminate their use in the subsequent experiments (Table 6).

Table 6: Effect of surfactant.

\begin{tabular}{|c|c|c|c|c|c|c|c|c|c|c|c|c|}
\hline \multirow{3}{*}{$\begin{array}{c}\text { Surfactant } \\
\text { solution }\end{array}$} & \multicolumn{12}{|c|}{ Absorbance*/order**of addtion } \\
\hline & \multicolumn{2}{|c|}{$\mathbf{I}$} & \multicolumn{2}{|c|}{ II } & \multicolumn{2}{|c|}{ III } & \multicolumn{2}{|c|}{ IV } & \multicolumn{2}{|c|}{$\mathbf{V}$} & \multicolumn{2}{|c|}{ VI } \\
\hline & $\mathbf{A}$ & $\begin{array}{l}\Delta \lambda, \\
\mathbf{n m}\end{array}$ & $\mathbf{A}$ & $\begin{array}{l}\Delta \lambda, \\
\mathbf{n m}\end{array}$ & $\mathbf{A}$ & $\begin{array}{l}\Delta \lambda, \\
\mathbf{n m}\end{array}$ & $\mathbf{A}$ & $\begin{array}{l}\Delta \lambda, \\
\mathbf{n m}\end{array}$ & $\mathbf{A}$ & $\begin{array}{l}\Delta \lambda, \\
\mathbf{n m}\end{array}$ & $\mathbf{A}$ & $\begin{array}{l}\Delta \lambda, \\
\mathrm{nm}\end{array}$ \\
\hline $\begin{array}{c}\text { CТAB } \\
1 \times 10^{-3} \mathrm{M}\end{array}$ & 0.381 & 100 & 0.323 & 155 & 0.372 & 110 & 0.339 & 118 & 0.384 & 151 & 0.380 & 153 \\
\hline $\begin{array}{c}\text { SDS } \\
1 \times 10^{-3} \mathrm{M}\end{array}$ & 0.343 & 146 & 0.375 & 160 & 0.351 & 157 & 0.363 & 109 & 0.307 & 109 & 0.352 & 149 \\
\hline $\begin{array}{c}\text { Tritonx- } \\
100\end{array}$ & 0.312 & 160 & 0.373 & 168 & 0.361 & 168 & 0.346 & 146 & 0.325 & 147 & 0.305 & 143 \\
\hline
\end{tabular}

$* \mathrm{~A}=0.385$ without surfactant and $\Delta=153 \mathrm{~nm}$

** I. Mesalazine (M) +Surfactant(S) $+\mathrm{HCL}(\mathrm{H})+\mathrm{NaNO}_{2}(\mathrm{~N})+\operatorname{Sulphamic} \operatorname{acid}(\mathrm{F})$

+ Resorcinol(R) $+\mathrm{NaOH}(\mathrm{B})$

II. $\mathrm{M}+\mathrm{H}+\mathrm{S}+\mathrm{N}+\mathrm{F}+\mathrm{R}+\mathrm{B}$

III. $\mathrm{M}+\mathrm{H}+\mathrm{N}+\mathrm{S}+\mathrm{F}+\mathrm{R}+\mathrm{B}$

IV. $\mathrm{M}+\mathrm{H}+\mathrm{N}+\mathrm{F}+\mathrm{S}+\mathrm{R}+\mathrm{B}$

V.M $+\mathrm{H}+\mathrm{N}+\mathrm{F}+\mathrm{R}+\mathrm{S}+\mathrm{B}$

\section{Effect of base}

The preliminary experiments have shown that diazotized 5-ASA gave colored dye of highest intensity with resorcinol in alkaline medium, therefore the coupling reaction has been carried out with different (strong and weak) bases and the results show that sodium carbonate and sodium bicarbonate gave better sensitivity than sodium ydroxide and potassium hydroxide. But the later bases gave better color contrast $(\Delta \lambda)$, and the azo-dye formed has good stability compared with weak bases, so that $1.5 \mathrm{ml}$ of $1 \mathrm{~N}$ sodium hydroxide solution has been recommended for the subsequent experiments (Table7). 
Table 7: The effect of base on the absorbance and colour contrast

\begin{tabular}{|c|c|c|c|c|c|c|c|c|}
\hline \multirow{2}{*}{$\begin{array}{c}\text { Solution 1N } \\
\text { base used }\end{array}$} & \multirow{2}{*}{ Variable } & \multicolumn{7}{|c|}{ Absorbance / ml of base use } \\
\cline { 2 - 9 } & & $\mathbf{0 . 5}$ & $\mathbf{1}$ & $\mathbf{1 . 5}$ & $\mathbf{2}$ & $\mathbf{2 . 5}$ & $\mathbf{3}$ & $\mathbf{4}$ \\
\hline \multirow{2}{*}{$\mathrm{NaOH}$} & $\mathrm{A}$ & 0.330 & 0.329 & 0.387 & 0.331 & 0.251 & 0.233 & 0.194 \\
\cline { 2 - 9 } & $\boldsymbol{\Delta} \boldsymbol{\lambda} * \mathrm{~nm}$ & 128 & 153 & 154 & 163 & 168 & 149 & 143 \\
\hline \multirow{2}{*}{$\mathrm{KOH}$} & $\mathrm{A}$ & 0.304 & 0.298 & 0.309 & 0.313 & 0.294 & 0.267 & 0.221 \\
\cline { 2 - 9 } & $\Delta \lambda$ & 136 & 152 & 152 & 169 & 165 & 147 & 146 \\
\hline \multirow{2}{*}{$\mathrm{Na}_{2} \mathrm{CO}_{3} * *$} & $\mathrm{~A}$ & 0.649 & 0.640 & 0.726 & 0.732 & 1.042 & 0.811 & 0.739 \\
\cline { 2 - 9 } & $\Delta \lambda$ & 8 & 18 & 27 & 26 & 27 & 11 & 36 \\
\hline \multirow{2}{*}{$\mathrm{NaHCO}_{3} * *$} & $\mathrm{~A}$ & 0.831 & 0.503 & 0.629 & 0.618 & 0.601 & 0.495 & 0.482 \\
\cline { 2 - 9 } & $\Delta \lambda$ & 17 & 25 & 23 & 23 & 29 & 30 & 34 \\
\hline
\end{tabular}

$\Delta \lambda *=\Delta \lambda_{\max }-\Delta \lambda_{\operatorname{maxB}} S=$ The dye

$\mathrm{B}=\mathrm{Blank}$

$* *$ Gives unstable azo-dye

\section{Final absorption spectra}

When mesalazine is treated according to the recommended procedure, the absorption spectrum shows a maximum absorption at $471 \mathrm{~nm}$, characteristic of the orange dye .The reagent blank shows nill absorption at the wavelength of maximum absorption (Fig. 2).

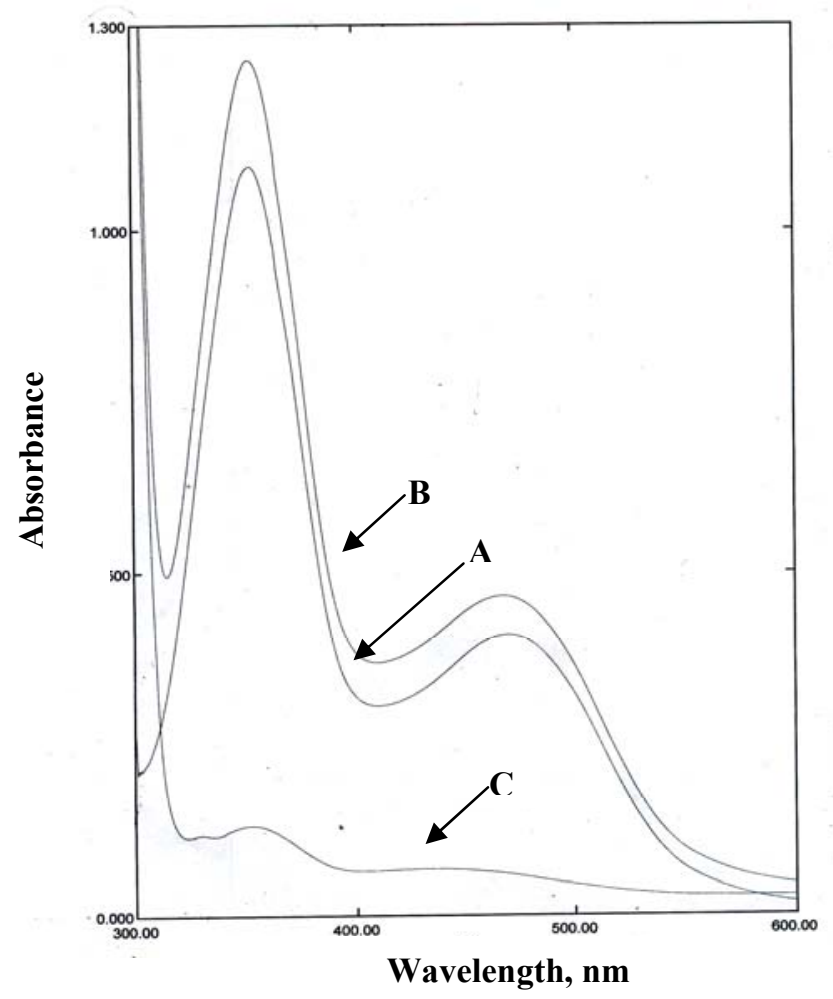

Fig. 2: Absorption spectra of $50 \mu \mathrm{g}$ mesalazine / $25 \mathrm{ml}$ treated according to the recommended procedure and measured against (A) reagent blank, (B) distilled water and $(C)$ reagent blank measured against distilled water 


\section{Accuracy and Precision}

Three different concentrations of 5-ASA are used in the determination of the accuracy and precision of the method, the results shown in Table 8 indicate that the method has good accuracy and precision.

Table 8: Accuracy and precision of the method

\begin{tabular}{|c|c|c|}
\hline $\begin{array}{c}\text { Amount of mesalazine } \\
\text { taken, } \boldsymbol{\mu g}\end{array}$ & Relative error, \%* & $\begin{array}{c}\text { Relative standard } \\
\text { deviation, \%* }\end{array}$ \\
\hline 20 & -0.96 & \pm 1.05 \\
\hline 50 & -0.83 & \pm 0.49 \\
\hline 100 & -0.23 & \pm 0.37 \\
\hline
\end{tabular}

* Average of five determinations

\section{Nature of the Dye}

The composition of the intense orange dye that results from the reaction ofdiazotized 5-ASA with resorcinol has been established using the continuous variations and the mole-ratio methods, the results indicate that the dye has a combination 1:1 ratio of diazotised 5-ASA to recorcinol (Fig. 3 and 4).

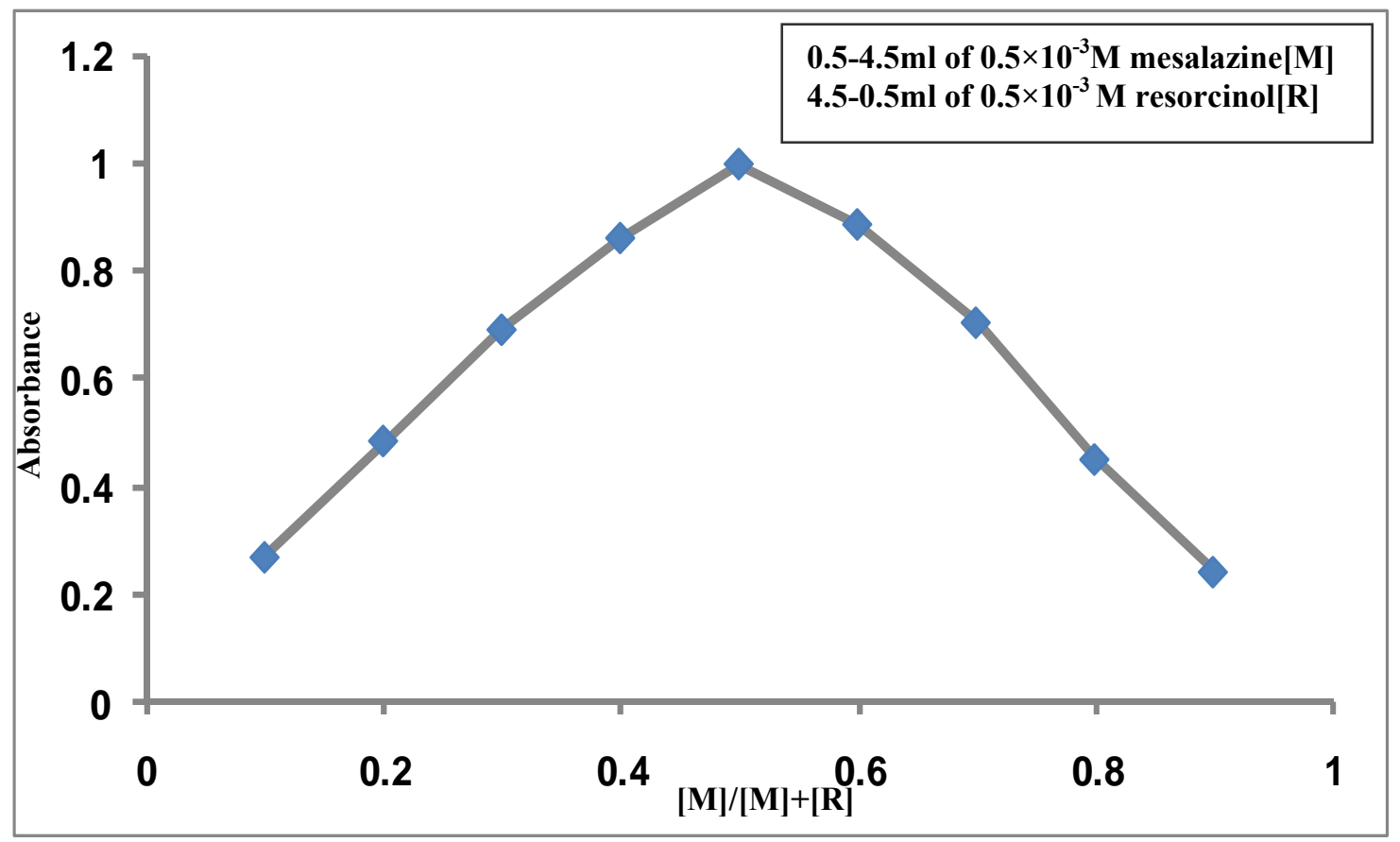

Fig. 3: The continuous variations plot for diazotized mesalazine to resorcinol 


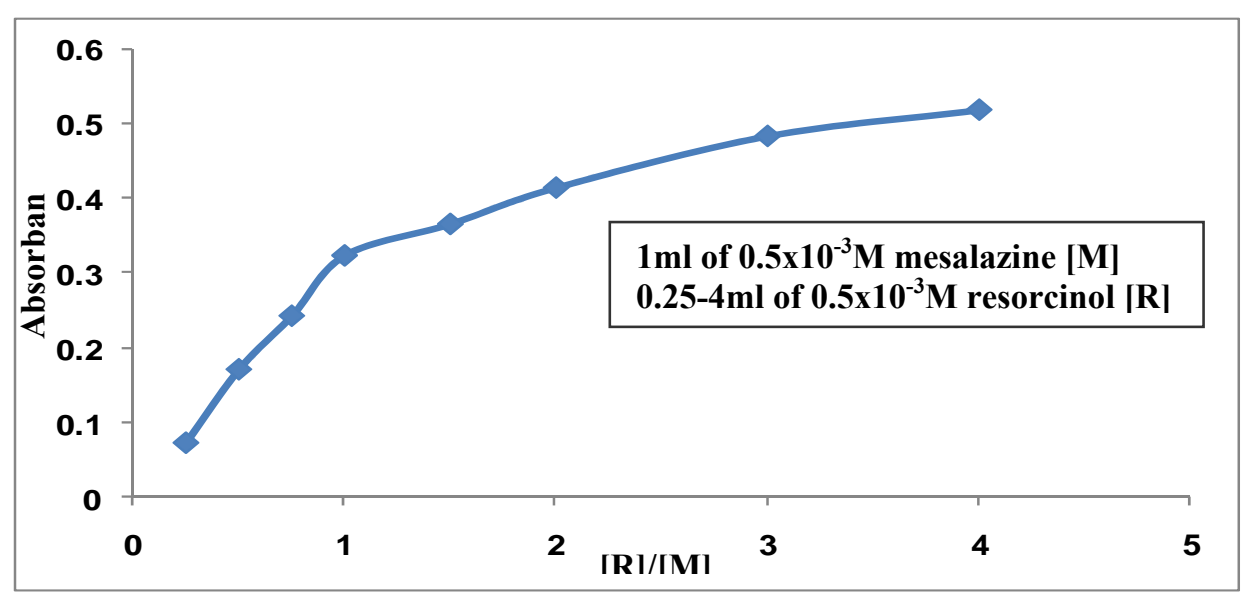

Fig. 4: The mole-ratio plot for diazotized mesalazine to resorcinol

Hence the dye may have the following suggested structure:

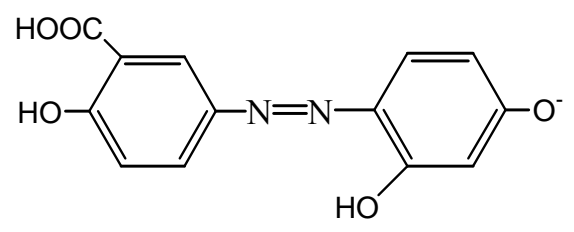

Orange azo-dye

\section{Interference}

The effect of some foreign compounds which often accompanied pharmaceutical preparations were studied by adding four different amounts $(50,200,500$ and $1000 \mu \mathrm{g})$ to $50 \mu \mathrm{g}$ mesalazine in a final volume $25 \mathrm{ml}$ (Table 9).

Table 9: Effect of foreign compounds for assay of mesalazine

\begin{tabular}{|c|c|c|c|c|}
\hline \multirow{2}{*}{$\begin{array}{c}\text { Foreign } \\
\text { Compound }\end{array}$} & \multicolumn{4}{|c|}{ Foreign compound added } \\
\cline { 2 - 5 } & $\mathbf{5 0}$ & $\mathbf{2 0 0}$ & $\mathbf{5 0 0}$ & $\mathbf{1 0 0 0}$ \\
\hline Glucose & 95.5 & 95.2 & 95.4 & 96.1 \\
\hline Lactose & 98.3 & 97.2 & 95.4 & 100.7 \\
\hline Starch & 94.7 & 97.2 & 100.3 & 95.5 \\
\hline GumArabic (Acacia) & 99.4 & 95.5 & 105.1 & 96.1 \\
\hline
\end{tabular}

The results in table indicated that the studied foreign compounds do not interfere in the determination of mesalazine using the proposed method. An error not more than of $5.1 \%$ in the absorbance readings is considered tolerable from that of the mesalazine alone. 


\section{Application of the method}

To test the applicability of the present method, it has been applied to the determination of 5-ASA in pharmaceutical preparation (capsules). On applying proposed procedure, good recovery is obtained as shown in

Table 10 .

Table 10: Application of the method

\begin{tabular}{|c|c|c|c|}
\hline Drug & $\begin{array}{c}\boldsymbol{\mu g} \text { mesalazine } \\
\text { present/25ml }\end{array}$ & $\begin{array}{c}\boldsymbol{\mu g} \text { mesalazine } \\
\text { measured/25ml }\end{array}$ & Recovery*, \% \\
\hline $\begin{array}{c}\text { Mesacol Extended } \\
\text { release capsules } \\
\mathbf{4 0 0} \text { mg Universal } \\
\text { pharmaceutical } \\
\text { Industries- } \\
\text { unipharma- } \\
\text { Damascus-Syria }\end{array}$ & 20 & 21.2 & 106.12 \\
\cline { 2 - 4 } & 100 & 100.73 & 100.52 \\
\hline
\end{tabular}

* Average of five determinations

\section{Evaluation of the proposed method}

Because there is no standard method in the literature for determination mesalasine, so that this standard addition method applied in order to prove that the proposed method can be used in the determination of mesalazine without interferences. (Table 11 and Fig. 5).

Table 11: The results of standard addition method

\begin{tabular}{|c|c|c|c|}
\hline Drug & $\begin{array}{c}\boldsymbol{\mu g} \text { mesalazine } \\
\text { present/25ml }\end{array}$ & $\begin{array}{c}\boldsymbol{\mu g} \text { mesalazine } \\
\text { measured/25ml }\end{array}$ & Recovery*, \% \\
\hline $\begin{array}{c}\text { Mesacol Extended } \\
\text { release capsules 400 } \\
\text { mg Universal } \\
\text { pharmaceutical } \\
\text { Industries- } \\
\text { unipharma- } \\
\text { Damascus-Syria }\end{array}$ & 20 & 19.7 & 98.5 \\
\cline { 2 - 4 } & 40 & 40.1 & 100.25 \\
\hline
\end{tabular}

* Average of three determinations 


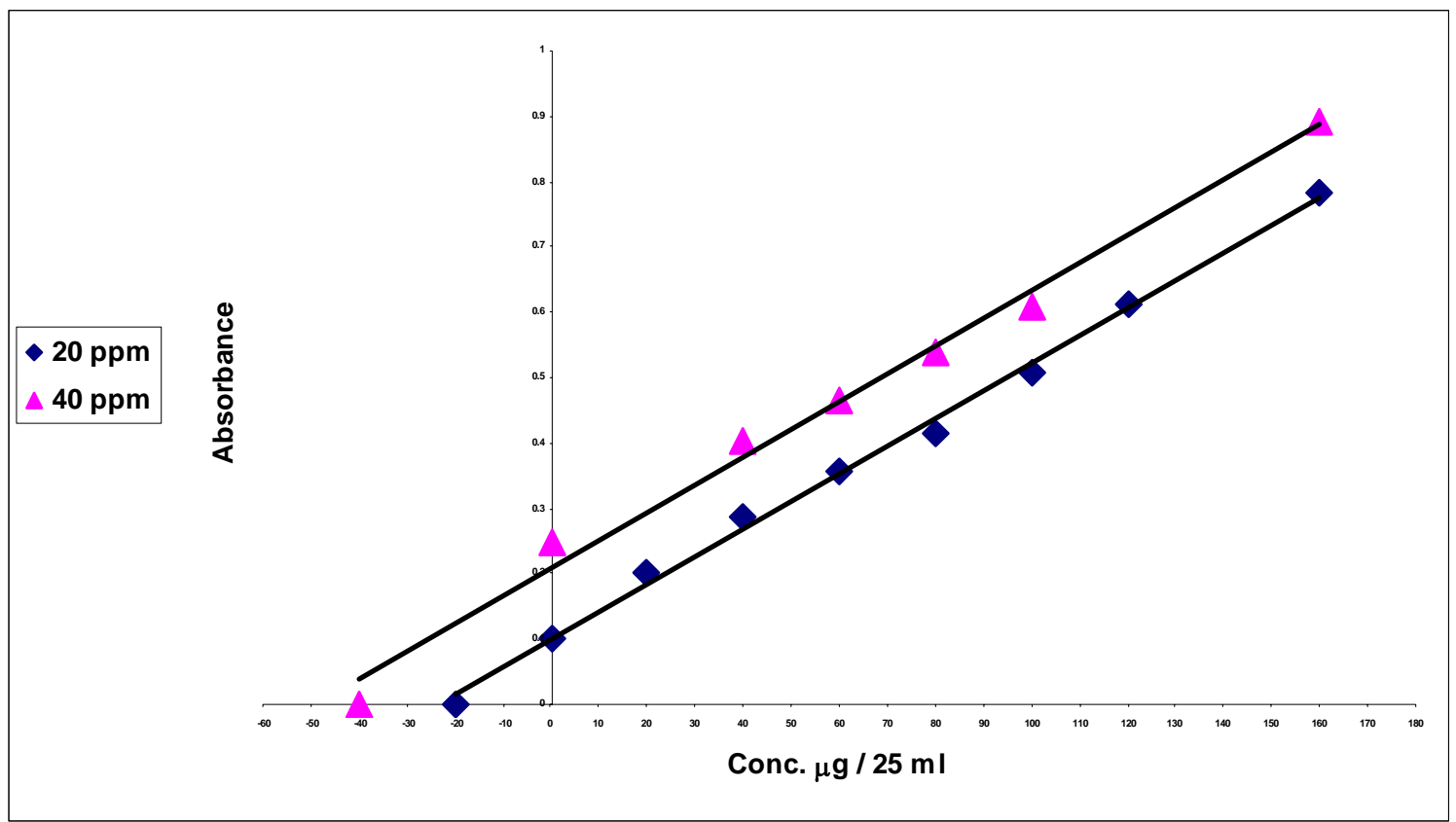

Fig.5: Graphs of standard addition method for the determination of mesalazine in pharmaceutical preparations (capsules).

The results in Table 11 and Fig. 5 indicated that the proposed method can be used to determine mesalazine in pharmaceutical preparation (capsules) with satisfactory results.

\section{Comparison of Methods}

Table 12 shows the comparison between the analytical variables obtained from the present method with those of recent spectrophotometric method. 
Table 12: Comparison of the methods

\begin{tabular}{|c|c|c|}
\hline Analytical parameters & Present method & Literature method* \\
\hline $\mathrm{pH}$ & 12.38 & $\geq 12$ \\
\hline Temperature $\left({ }^{\circ} \mathrm{C}\right)$ & At room temperature & At room temperature \\
\hline $\begin{array}{l}\text { Development time } \\
\text { (minutes) }\end{array}$ & 10 & 5 \\
\hline$\lambda_{\max }(\mathrm{nm})$ & 471 & 610 \\
\hline Medium of method & Aqueous & Aqueous \\
\hline Type of reaction & Diazotisation & Oxidative coupling \\
\hline Reagent & Resorcinol & 2,6-xylenol \\
\hline Beer's law range (ppm) & $0.4-12$ & $0.16-18$ \\
\hline $\begin{array}{l}\text { Molar absorptivity } \\
\left(1 . \mathrm{mol}^{-1} \cdot \mathrm{cm}^{-1}\right)\end{array}$ & $2.9479 \times 10^{4}$ & $1.3116 \times 10^{4}$ \\
\hline RSD (\%) & \pm 1.05 to $\pm 0.37 \%$ & $\pm 1.23 \mathrm{o} \pm 1.01 \%$ \\
\hline Color of the dye & Orange & Blue \\
\hline Nature of the dye & $1: 1$ & $1: 1$ \\
\hline $\begin{array}{l}\text { Application of the } \\
\text { method }\end{array}$ & $\begin{array}{l}\text { Determination of } \\
\text { mesalazine in capsules }\end{array}$ & $\begin{array}{l}\text { Determination of } \\
\text { mesalazine in two drugs } \\
\text { (capsules and tablets) }\end{array}$ \\
\hline
\end{tabular}

Al-Fakhry M.H. 2006. M.Sc., Thesis, Mosul University, 64-80.

The proposed method is simple, rapid, sensitive and do not need any pretreatment of mesalazine or extraction of the dye formed and has good precision.

\section{REFERENCES}

Abdullin I.F.; Chernysheva N.N. and Budnikov G.K., 2002. Galvanostatic Coulometric Determination of Salicylic Acid and Some of Its Derivatives Using Electrogenerated Halogens, J. Anal. Chem., 57, 8: pp.721-723.

Al-Fakhry M.H., 2006. M.Sc., Thesis. The Use of Oxidative Coupling Reactions for Spectrophotometric Determination of Aniline and Its Substituents and the Drugs Dipyrone and Mesalazine, Mosul University, Mosul, Iraq, pp. 64-80.

Bladyga J. and Bourne J.R.,1999. Turbulent Mixing and Chemical Reactions,Johon Wiley and Sons, Inc., New York, 644 p. 
Bystrowska B.; Nowak J. and Brandys J., 2000. Validation of a C Method for the Determination of 5-Aminosalicylic Acid and its Metabolite in Plasma and Urine, J. Pharm. Biomed. Anal., 22: pp.341-347.

Gotti R.; Pomponio R.; Bertucci C. and Carrini V., 2001. Determination of 5Aminosalicylic Acid Related Impurities by Micellar Electrokinetic Chromatography with an Ion-pair Reagent, J. Chromatogr. A, 916: pp. 175-183.

Liu ZC.; Celland RA. and Uetrecht JP., 1995. Oxidation of 5-Aminosalicylic Acid by Hypochlorous Acid to a Relative Iminoquinone. Possible Role in the Treatment of Inflammatory Bowel Disease, J. Pharmacol. And Exp. Thearp. Soc., Am., 23: pp.246-250.

Lupetti K.O.; Rocha F.R. and Filho O.F., 2004. An Improved Flow System for Phenols Determination Exploiting Multicomm-tation and Long Path Length Spectrophotometry, Talanta, 62: pp.463-467 .

Nigovic B. and Imunic B., 2003. Determination of 5-Aminosalicylic acid in Pharmaceutical Formulation by Differential Pulse Voltammetry, J. Pharm. Biomed. Anal., 31: pp.169-174.

Nobilis M.; Vybiralova Z.; Sladkova K.; Lisa M.; Holcapek M. and Kvetina J., 2006. High-Performance Liquid Chromatogra-phic Determination of 5Aminosalicylic Acid and Its Metabolites in Blood Plasma, J. Chromatogr. A, 1119: pp. 299-308.

Pieniaszek HJ. and Bates TR., 1975. Colorimetric Determination of 5-Aminosalicylic Acid and Its N-acetylated Metabolite on Urine and Feces, Res. Commun. Chem. Pathol. Pharma-col., 12: pp. 571-581.

Rafael J.A., Jabor.; Casagrande R.; Georgetti S.R.; Borin M.F. and Fonseca M.V., 2007. Validation of HPLC, DPPH and Nitrosation Methods for Mesalazine Determination in Pharmaceutical Dosage Forms, Brazilian J. Pharm. Sci., 43: 1p. 